\title{
SITES OF EXCLUSION AND SITES OF INCLUSION: SPATIAL AND ENVIRONMENTAL LIMINALITIES IN JIMMY SANTIAGO BACA'S MEMOIR, WORKING IN THE DARK: REFLECTIONS OF A BARRIO POET (1992)
}

\author{
Sophia Emmanouilidou \\ Aristotle University of Thessaloniki, Greece
}

\begin{abstract}
In a world-order articulated by a plethora of scientific/technological data, selfhood remains more elusive than ever. Identity-representation undergoes multiple and often overlapping metamorphoses, while the sense of self seems to be entangled in a constant rite to being, instead of aiming at a definitive crystallization. The aim of this paper is to explore sites of social interaction/control and the environmental liminalities arising at the interstices between subjugation and freedom (exclusion and inclusion). Jimmy Santiago Baca's quasi autobiography Working in the Dark (1992) establishes the unnatural premises of a prison house as the locus for the birth of engaged poetry. This text rethinks the troubled relationship between Humans and Nature, and becomes powerful testimonials of discrimination and prejudice, as well as avowed commitments to an ethnic group's struggle to transgress prescribed modes of existence.
\end{abstract}

KeYwords: Santiago Baca, identity-representation, liminality, human-nature problematization.

\section{SITIOS DE EXCLUSIÓN Y SITIOS DE INCLUSIÓN: LIMINALIDADES ESPACIALES \\ Y AMBIENTALES EN LAS MEMORIAS DE JIMMY SANTIAGO BACA, WORKING IN THE DARK: REFLECTIONS OF A BARRIO POET (1992)}

\section{RESUMEN}

En un orden mundial articulado por una plétora de datos científico-tecnológicos, la esencia del ser parece más inasible que nunca. La representación identitaria se somete a múltiples, y a menudo solapadas, metamorfosis, mientras el yo parece enmarañarse en un ritual constante sin alcanzar una cristalización definitiva. Es el próposito de este artículo explorar aspectos del control y la interacción social, así como las liminalidades del entorno, que surgen de los intersticios entre el sometimiento y la libertad (la inclusión y la exclusión). En su quasi autobiografía Working in the Dark (1992), Jimmy Santiago Baca establece los aposentos de una prisión como el lugar para el nacimiento de una poesía comprometida. Este texto reformula la complicada relación entre los Humanos y la Naturaleza, y deviene un poderoso testimonio sobre la discriminación y los prejuicios, al tiempo que un compromiso declarado con la lucha de un grupo étnico por trascender los modelos prescritos de existencia.

Palabras Clave: Santiago Baca, representación identitaria, liminalidad, problemática humano/naturaleza.

DOI: https://doi.org/10.25145/j.recaesin.2018.77.10

Revista Canaria de Estudios IngLeses, 77; november 2018, pp. 149-162; ISSN: e-2530-8335 
In my prison cell I had vowed that if the world did not let me in, someday I would welcome the world into my world. (Jimmy Santiago Baca. Working in the Dark: Reflections of a Barrio Poet, 109).

One should stress the importance and significance which, in the modern world, political parties have in the elaboration and diffusion of conceptions of the world, because essentially what they do is to work out the ethics and the politics corresponding to these conceptions and act as it were as their historical 'labora-

tory.' (Antonio Gramsci "Notes for an Introduction and an Approach to the Study of Philosophy and the History of Culture" 335).

\section{INTRODUCTION: SPATIAL MATERIALITIES AND IDENTITY FORMATION}

In a world order articulated through a plethora of scientific, technological and economic data (notably quite incomprehensible to the average world citizen), selfhood remains more elusive than ever. Instead of aiming at a state of definitive crystallization, identity representation undergoes multiple and often overlapping metamorphoses. In this context, the sense of self seems to be entangled in a constant mutation or trapped in a perpetual rite of being. At the juncture of an identity crisis, the hermeneutics of history have obstinately monopolized anthropocentric explanations of culture and selfhood. ${ }^{1}$ Put differently, historical treatises have primarily focused on humanity's clashes, interactions and coalitions in order to account for the political, social and cultural musings taking place across the globe. Yet, the historical approach has resulted in a profound estrangement of both individual and communal identities from the materialities of space. In fact, although the bulk of historical landmark texts often make reference to specific landscapes and locales, this process occurs in the course of assessing the more abstract facets of human enactment instead of attributing value markers to concrete and readily identifiable spatial matrixes.

What seems to be lacking in historical explanations of humanity's formations, accords and deeds is a lucid reference to space as a value marker in the crises arising from the series of unsustainable schemes concocted by human cultures and then enforced by (inter)national politics. Such crises are evidenced in scientific records of resource exploitation, soil erosion, species extinction and environmental racism, all fundamentally related to the notion of topos. If the critical eye follows

1 Timothy Clark sums up the term anthropocentrism as "any stance, perception or conception that takes the human as centre or norm. An 'anthropocentric' view of the natural world thus sees it entirely in relation to the human, for instance as a resource for economic use, or as the expression of certain social or cultural values-so even an aesthetics of language appreciation can be anthropocentric" (3). 
historical accounts of societal structures until the rise of the Environmental Movement (roughly dating back to the middle of the 1960s), then human agents roam planet Earth's spatial confines as indisputable rulers, self-righteous perpetrators and despotic looters of a given landscape's resources and biota. In short, whether in the course of imperialism, colonialism or postcolonialism, human presence coincides with a superficial treatment of both natural landscapes and the sum total of living creatures in them as sites or entities to be exploited for lucrative ends. ${ }^{2}$

On the antipodes, the discourses propounded by numerous philosophers such as Yi-Fu Tuan (1977), Victor Turner (1982), Michel Foucault (1998), Edward W. Soja (1989), Homi Bhabha (1990) and Henry Lefebvre (1991) postulate a theoretical turn to the practicalities of spatial experience, in order to highlight those often disregarded material significations embedded in the course to self-cognizance. The hermeneutics of space reveal the dynamics of environmental positioning and explore grassroots attempts at self-regulation both in spatial and temporal terms. Without devaluing the significance of time in their interpretations of human affairs, the above mentioned philosophers present diverse and yet convergent perspectives on how space is invested with the issues of cultural awareness, political alignment, national identity and self-formation. The intriguing writings of these philosophers focus on the perplexities of space in order to allow the Earth's locales to emerge as carriers of meaning and defining factors in the scribbling of history. Places, however, are polysemous and multi-layered precisely because they include both biotic and abiotic factors in their composition. Moreover, in the ecocentric approach, we need to take into consideration the fact that there is a wide array of interrelations and interconnections at play in any study of the organic and inorganic matrixes of ecosystemic structure. More precisely and judging by the current environmental crisis sweeping the planet, human agency certainly plays a crucial role in the modification of a biome's spatial characteristics, but there is also the parameter of a landscape's or place's physicality per se which define human cultures and substantiate entrepreneurial endeavours, socio-cultural communalities and self-identities. Along these lines, the "environmental imagination" of an ecocritical study often employs the concept of place in order to enlighten "the inevitable but uncertain and shifting relation between being and physical context" (Buell 62). ${ }^{3}$

2 Reference needs to be made to the concept of biocentrism, which could be roughly considered as the polar opposite term to anthropocentrism. According to the ecocentric theories set forth by Deep Ecologists, the pending shift from the human centered manner of thinking includes the recognition of the inherent value in the sum total of nature's living and non-living forms, entails the radical reconsideration of Western philosophy and strengthens the democratic ethos in societies: "Deep ecology is concerned with encouraging an egalitarian attitude on the part of humans not only toward all members of the ecosphere, but even toward all identifiable entities or forms in the ecosphere. Thus, this attitude is intended to extend, for example, to such entities (or forms) as rivers, landscapes, and even species and social systems considered in their own right" (Sessions 270).

3 Lawrence Buell examines the concept of place in a decentring and destabilizing fashion seeking the "translocal-ultimately global-forces" that define it (63). For Buell, the concept of space 
The bulk of Chicano writings composed since the rise of El Movimiento in the 1960s has aptly negotiated the notion of topos (urban, rural and the wilderness) as central to the specific ethnic group's agonizing over a communal identity and to Chicanismo's struggles for legitimate citizenship in the U.S. ${ }^{4}$ Between the antipodes of White American marginalization of mexicano encultured spaces and La Raza's cries for pride within cultured localities, Chicano artists affirm the brown peoples' solidarity and validate the significance of the grouping's spatial and environmental representations. Chicano writings offer a valuable repository for in-depth ecodiscourse since the grouping's literary canon reveals an enlightened preoccupation with an environmentally thematic core. In effect, the ecocritical reading of Chicano literature aligns with the tendency to embrace the spatial parameter. In an attempt at tackling identity formation and making the shift towards "a more comparative, transcultural approach to ecocritical studies," Chicano literature offers ample material for environmental thinking that first reaches beyond topophilic attachments and second aims at the cosmopolitan reconsideration of environmental issues (Slovic 6). ${ }^{5}$

The aim of this paper is to explore a correctional institution as a site of social interaction and personal reformulation and to look into the environmental liminalities arising at the interstices between such antithetical notions as subjugation and freedom, negation and affirmation, exclusion and inclusion. Jimmy Santiago Baca's quasi-autobiography, Working in the Dark: Reflections of a Barrio Poet (1992) establishes a prison house as the locus for cultural empowerment and the birth of engagé poetry. The text becomes a powerful testimonio of discrimination, prejudice and marginalization as well as an avowed commitment to an ethnic group in the midst of the writer's personal struggle to transgress the self-depreciating narratives inflicted on him within a limiting and racist ideological context. In Baca's memoir, the prison initially "comes to represent the embodiment of industrialization, control, and technological vacuity" but then transmogrifies into a potent locale for the implementation of self-appreciation and for the rediscovery of the writer's attachment to nature (Pérez-Torres 115). In line with Ramon Saldívar's claim that the Chicano narrative evinces a culture of difference that "provide[s] readers with heterogeneous frameworks," this paper examines the ways in which Baca succeeds in transgressing the barriers of physical captivity and environmental estrangement during his

is elusive because it "gestures in at least three dimensions at once-toward environmental materiality, toward social perception or construction, and toward individual affect or bond" (63).

${ }^{4}$ For a concise introduction to the Chicano literary canon, see Francisco A. Lomelí and Donaldo W. Urioste (1985), Julio A. Martínez and Francisco A. Lomelí (1986).

5 At this point, reference needs to be made to Patrick D. Murphy who highlights the importance of a transcultural turn in ecocriticism. In the book, Farther Afield in the Study of Nature-Oriented Literature (2000), Murphy contends that the ecoresponses of numerous ethnicities in literary genres reveal a structure of self-cognizance and simultaneously promote the democratic ethos in the realms of literary criticism: "In order to widen the understanding of readers and critics, it is necessary to reconsider the privileging of certain genres and also the privileging of certain national literatures and certain ethnicities within those national literatures. Such reconsideration will enable a greater inclusiveness of literatures from around the world within the conception of nature-oriented literature" (58). 
imprisonment with the extensive use of nature imagery and the introduction of a series of self-identity liminalities (7). ${ }^{6}$

\section{THE LIMINALITIES OF POETIC ECODISCOURSE AND THE PINTO POET'S IDENTITY}

Working in the Dark (1992) is an illuminating detour into the tensions and crises Jimmy Santiago Baca experienced in a federal prison of the U.S. With rough candour, Baca explores the personal and cultural negotiations he underwent as an inmate, experiences which eventually led to the welding of his unique poetic voice. Imprisoned in his late teens on suspicion of murder and then on drug possession, Baca spent three out of the total seven years of his incarceration in confinement. Amidst the atrocities and brutalities in the U.S. penitentiary, Baca devises an odd antidote so as to sustain his human integrity: the acquisition and then the development of basic reading and writing skills. Baca confesses to mastering the ability to read and write in the alienating space of a prison. Until this turning point in his life, he admits to having felt like a prey "a target in the cross hairs of a hunter's rifle. [...] the hang-rope tighten around [his] neck and the trapdoor creak beneath [his] feet. There was nothing so humiliating as being unable to express [him]self, and [his] inarticulateness increased [his] sense of jeopardy, of being endangered" (4). Baca's initial experience in the prison is of a voiceless being, shockingly stripped of the basic right to convey meaning. Yet, during his contextualization as an illiterate convict, Baca seizes the opportunity to reset the factual topographical details of the prison and to redefine it as "a container" of cultural, social and personal meaning (Buell 63). Initially, he negotiates the interconnectedness between place and self-identity and then resorts to nature imagery in order to testify to the traumatic experiences of an uneducated Chicano adolescent: he portrays himself as an endangered species consumed with the "sense of teetering on a rotting plank over swamp water where famished alligators clapped their horny snouts for [his] blood" (4). In this gruesome image, Baca is exemplified as a helpless being to be sacrificed, standing in solitude on the rotten altar of a decaying society.

Baca is in essence a pinto (prison) poet, who "during one of his periods of imprisonment, in a desolate time when it seemed as if everything of human dignity and aspiration had been stripped from him, [...] turned to the empowerment of the word" $(\mathrm{x}) .^{7}$ Consumed by his state of desperation and denigration, Baca discovers

${ }^{6}$ The leading Chicano literary critic, Ramon Saldívar, argues that "Chicano narratives, individually as texts and together as a genre, confront and circumscribe the limiting ideologies imposed upon them [...]. As resistant ideological forces in their own right, their function is to shape modes of perception in order to effect new ways of interpreting social reality and to produce in turn a general social, spiritual and literary revaluation of values" (6-7).

7 Pérez-Torres approaches pinto poetry as a unique poetic expression in the Chicano literary canon which "stands as the quintessential product of contemporary American society, with its 
the world of poetry, which empowers him "by giving voice to a complicated and contradictory consciousness in the struggle with injustice" (Pérez-Torres 121). The poetic language in the works of "Neruda, Paz, Sabines, Nemerov and Hemingway" become "the magic that could liberate [him] from [himself], transform [him] into another person, transport [him] to other places far away" (4). The paradox is that Baca withstands his imprisonment and dehumanization in prison by reading the poems in a university textbook he steals from a prison warden. The lyrical words in the book embolden Baca and enable him to transgress temporal and spatial confines. The book of poetry he snatches evokes "memories [...] glowing with a strange but familiar intimacy in which [he] found refuge" (6). In due time, the composition of his enticing lyrics and the development of his unique poetic voice arise as a declaration of his self-identity and as a proclamation against the injustices inflicted upon Chicanismo across the U.S. Baca's poetic logos is compared to the stately mass of "an island rising beneath [his] feet like the back of a whale" (7). Thus, the composition of poetry serves as a safety net or an escape mechanism and a manifesto of liberation in the face of the ordeals he experiences during his incarceration.

Upon entering the state of forcible detention in prison, Baca is instantly excluded from organized society and also displaced into an inhumane and unnatural "hierarchy of brutality" (14). The space of the prison attains unruly dimensions and Baca is transformed into an emotionless animate being.

My life had compressed itself into an unbearable dread of being. The strain had been too much. I had stepped over that line where a human being has lost more than he can bear, where the pain is too intense, and he knows he is changed forever. I was now capable of killing, coldly and without feeling. I was empty, as I have never, before or since, known emptiness. I had no connection to this life. (10)

As Baca succumbs to a dehumanized state of being, he is instantly faced with the polarity of the civilized man and the savage. This division gives rise to numerous and overlapping repercussions in Baca's identity profile that evince the barbaric practices of institutional imprisonment. In fact, incarceration entails a series of interrelated significations for the autobiographer: Baca is caught in a network of deviancy, categorized as a criminal and forcefully marginalized from hegemonic society. In this outlaw condition Baca enters a site that Michel Foucault labels a heterotopia of deviancy. ${ }^{8}$ Heterotopias are in essence spaces laden with the intricate axiomatic interests of socio-political inclusion and exclusion, incorporation and marginalization. Thus, Baca is excluded from hegemonic society, but he is instantly included in a quaint system of moral values, which conceives of itself in the peripheries of society.

dehumanizing processes, its violence, its rigidity, its sterile and murderous environment. As such, pinto poetry scrutinizes the underside of American power" (115). For Pérez-Torres, pinto poetry manifests itself as oppositional to white American society but also as the product of the intricate social configurations forming between ethnic subjects and the dominant society.

${ }^{8}$ For the concept of heterotopias, see Foucault (1998). 
Incarceration is Baca's ostracization from dominant society, but it also introduces him to a novel environment that enables him to reassess his social attachments and rediscover his racialized and cultured self. In other words, he is being displaced from the mainstream, but he is on reflection emplaced in a locale which enables him to revaluate and reconceptualise his identity-profile. Baca's heterotopia of deviancy escapes the stereotypic definition of a quaint site of segregation for deviant subjects. Instead, the space of the prison affirms itself as a site that validates inspiration and poetic diction. In short, the notion of exclusion intersects with that of inclusion. And the negation of a subject's full-fledged social role (whether this negation is forceful or voluntary is immaterial, for the purposes of this paper at least) gives rises to a new set of connections and relations with the animate world and its inanimate elements. With the claim that "in creativity the dualities of life collide," Baca establishes an aura of optimism and echoes the paradoxical precept that institutional control creates the opportunities for the manifestation of resistance (66).

Both as a poet and a character, Baca functions as a trickster figure endowed with the liberties of liminality. ${ }^{9}$ Liminality is a subversive notion which encompasses layers of socio-cultural syncretism, rebellious behavior and the formation of new ideas, symbols, models and beliefs. The liminal subject opts for a freer existence, or "freedom from a whole heap of institutional obligations" (Turner 36). As a trickster figure, Baca enters various liminalities, disobeys standardized rules of conduct, resists classification, resorts to societal deconstruction and uses the tools of language in unconventional and subversive ways. Accordingly, Working in the Dark flirts with a series of liminalities since it emerges as a distinctive and mutating work of literature. In fact, Baca ingeniously conflates the genres of autobiography, fiction, poetry and literary criticism and publishes a book that is simultaneously and intensely rich both in lyricism and realism. The style of the memoir hints at a mischief against any stereotyped writing traditions and proves that Baca has "no use for pampered poets of the academy, or the darlings of fashion" (41). Moreover, Baca opts for the "redemptive power" of literature and thus disengages himself from any master-narratives of control like "government grants and academic security" that stifle the poet (41) (42).

Endowed with the liminal self-identity of a pinto poet, Baca advances on a treacherous path towards self-realization, or undergoes what Victor Turner terms a "threshold stage" of existence (36). During this stage in self-cognizance, Baca negotiates his social standing and resists prescribed modes of conduct. Indeed, Working in the Dark reveals numerous overlapping liminal situations that cement Baca's unconventionality: the autobiographer portrays himself as a hyphenated American citizen of mexicano ancestry, a former convict and a renowned poet who received his

9 Baca's trickster attributes arise in tune with his poetic mastery and cultural self-consciousness. Instead of opting for the more common mythical essence of a trickster figure, Baca projects his poetry as a means to resisting the U.S. penal system of control. Thus, his poetic craft is a rhetoric of resistance or the unconventional weapon of literary composition that fights his ostracization by dominant socio-cultural norms. For more on the trickster figure as a rebellious cultural hero who utilizes the socio-cultural tools of oppression to rebel, see Henry Louis Gates (2004). 
academic education long after resuming his poetic prestigious acknowledgement, a barrio junky and a loving father and husband. His liminalities allow him to question structures, material surroundings and his own self-identity.

Isn't poetry about transformation? Isn't it about interior landscapes colliding and realigning our vision of life, readjusting our inner borders so that the very idea of borders vanishes and we are confronted with the open space of limitless possibilities. $(60-61)$

Poetry aids Baca in overcoming the detrimental effects of the incessant monotony and unjust dehumanization of organized society. He transgresses preset boundaries of existence, searches for the "interior landscapes" and looks at the liminal spaces that define his humanness.

In accordance with the ecocritical approach to nature, Baca challenges institutional power with "implicit projections of what human identity is in relation to the non-human, with ideas of the wild, of nature as refuge or nature as resource, nature as the space of the outcast, of sin and perversity, nature as a space of metamorphosis or redemption" (Clarke 6). Indeed, Baca insists on perplexing his cognition processes, devising for himself multiple liminalities and presenting the readers with multi-layered interpretations of selfhood. He also avoids the acquisition of a cemented self-identity in an astute manner. In fact, Baca juggles with a series of antithetical imagery as life and death, decay and resurgence, darkness and enlightenment, love and hatred, piety and rage, urban life and the environment, the llano and the barrio, the mesa and the prison cell. Baca claims that his poetry is "both painful and ecstatic to hear and to write," "a profound appetite for death and resurrection; a rage to destroy and create anew [...], to partake the mystery of your own dying and living" (59). Baca construes the poetic craft as the power to create alternative systemic modes to self-identification that defy monolithic narratives of control. Moreover, it is his success as a poet that leads to the awakening of his nullified senses and a profound eroticism "like the stag must feel his first spring, when buck fever swells his cock and he bellows for a doe" (109). In tune with the theme of plurality running through the text, Baca rebels against fossilized creeds of personal success and institutional power, and in doing so he sustains his primary aim to conflate destructive as well as reconstructive rituals of existence. His personal life story serves as an example par excellence of a person who has survived the atrocities of prison, "the pain in the soul, the twisting and slamming in [his] guts, like a desperate hand beating on a door" only to rise as a successful poet (51). This transformation entails that once he accedes to his poetic identity, he can tear down the labels attributed to him by mainstream society.

Baca attains his personal freedom by being in physical captivity. Such a paradoxical rite of passage allows him to gain the freedom of liminality and to develop metamorphic abilities. While transgressing the attribute of a Mexican American deviant con, Baca becomes "the black wolf that tracks across [the] snowy public lives" (58). Animal representation is socially and "culturally contingent" in this instance because Baca depicts himself as a loner who lurks in the woods in defiance of the 
white American lifestyle (Garrard 155). As an engaged Mexican American poet who oddly oscillates between captivity and poetic sovereignty, Baca persistently abolishes the boundary between humans and animals. ${ }^{10}$ Baca's self-representation establishes that "[h]umans can both be, and be compared to, animals. Here, is therefore, an extensive 'rhetoric of animality,' [...] which is as functional in descriptions of human social and political relations as it is in describing actual animals" (Garrard 153). In this light, Baca employs the ecocritical technique of understanding his humanity "zoomorphically" (Garrard 160). Indeed, Baca grasps the complexities of his selfidentity in a cycle of animal representations which permit him to enter different landscapes, as in becoming "the rebellious wolf-cub, who has wept between [his] grandmother-wolf's gnarled paws, and laughed and howled with her under the moon on the mesa" (98). His transformations pertain to both terrestrial and aquatic ecosystems, biotic and abiotic factors. Baca "makes of the poet a burning sun that gives birth to a million shadows," or he "dive[s] down like a dolphin, breaking the surface briefly to check the shoreline and submerging [him] self once more into the strange blue underworld of the image and of memory, [his] writing hand cleaving its way as naturally as the dolphin's tail-fin" (67) (64).

Baca's liminality of an acknowledged pinto poet from the margins of society grants him the freedom to resume the role of a collective voice and to "rake poetry in from the ash piles, combing for the teeth and bone shards of those who died anonymous deaths" (58). His poetry collections and fiction writings speak for the Chicano migrant worker and the land of his toil, the "llano men [...] unafraid of death, surviving the edge with scarce sustenance, caressing the earth with great humility" (26). Nonetheless, his writings surpass the power of the poet, resume their own forcefulness, release themselves from the page and direct Baca in communal detours across space and time. Baca reflects on his literary writings as "words like spirit-sticks tap out of songs, calling upon the darkness to evoke the spirits of our Chicano ancestors-Mayan, Olmec, Aztec, Mexican-and to make of their music one Chicano song. Their breath, blowing through the hollow flute-shoots of my bones, gives me the song of blue corn and Rio Grande water and pinto beans and green chile ... and carnalismo" (28-29). In search of a collective consciousness, Baca relinquishes the power of ecoliterary creativity and ventures on a virtual trip to the encultured landscape of New Mexico.

${ }^{10}$ In his landmark book Ecocritism, Greg Garrard refers to the various ways that animals are portrayed in human cultures: "Once contiguity (metonymy) is granted, animals may be understood in human terms (anthropomorphism) or human in animal terms (zoomorphism), and each of these appears in both crude and sophisticated, critical forms. Even if animals are represented as different to humans, that difference can be construed as a deficit (mechanomorphism) or, rarely, as a kind of superiority (allomorphism)" (154). Baca often resorts to zoomorphism as a viable means of rejecting the socio-culturally invested aspects of his ethnic identity. It should also be noted that Baca's metamorphoses encompass a wide array of forms which supersede the animal transformations of the naguales in Mesoamerican folk religion. For an incisive approach to the religious practices and symbols in Mesoamerican beliefs, see León Portilla (1992). 
For me the poem lives not only on the page, for when I read aloud I relive the poem, become the poem, as it takes and remakes my body as well as my soul.

So, when the poem is angry, I too become angry as I read, and as the poem weeps, so do I. [...] I am myself Chicano, and I follow the wind-swept trail of my people, and how they convey emotion and song in their rituals. I turn to my landscape in New Mexico, listen to how the wind moans, look to how the mountain carves its space in the sky. I hear that silence of terrible resonance that buzzes in the prairie, a silence filled with spirits and the passion of growing things singing their seasonal fruition. From the cries of the barrio and the silence of the prairie come my Chicano blues, an earth-shaking, heart -moaning song." (62)

Once again, Baca enters a liminal condition in which he can rearrange the dynamics of sites and self-identities. Thus, he portrays himself as a poet in solitude staring at a page, a performer in front of a barrio public and a Mexican American who virtually roams the land of his ancestors in order to rediscover poetry as "the journey within, a poaching into the interior territories of life and death, that changes us in proportion to the courage of our forays there" (61). Embracing his liminal personhood, Baca successfully overcomes impediments of cognition and reinforces his own understanding of a complex world order from a nuanced viewpoint.

Working in the Dark is a subversive text of self-understanding that empowers Baca to repeatedly beam himself into various temporal zones and spatial locales. His memoir disperses meaning, evades categorizations and invites the poet's memory to unravel in polymorphic terms. The most striking fusion of antithetical and juxtaposing notions in Baca's testimonio is the subtle elaboration of the inside versus outside axiomatic difference. Baca destroys neat and convenient distinctions pertinent to this dichotomy. In a postmodern fashion, he readjusts obsolete notions that differentiate between inclusive and exclusive sites and seeks to formulate his self-identity afresh. Evoking his memory reservoir, effectively serves Baca's ends to hold a "grasp of one's one present and future in relation to the 'story' of one's embodied activity within particular spaces and with respect to particular objects and persons" (Malpas 180). But for Baca, spaces do not reflect vacant images for peripatetic comprehension; instead, they are invested with the lingering remnants of past experiences and future aspirations. Much in accordance to Lawrence Buell's space approach, Working in the Dark unfolds spatiality as "a place sense [...] a kind of palimpsest of serial place-experiences" (Buell 73). These experiences can be of a national, ethnic, communal or personal history, and they ascribe varied meanings to coinciding topographies and histories. In this light, Baca aims at a cosmopolitan view of social and environmental crises, as he ingeniously describes imprisonment in terms of the wilderness in Vietnam, and defines incarceration with images of the Asian jungles:

Outside everything is always changing, there are surprises, and you talk about that. But in prison the only news is old news. It is a dead land, filled with threat, where there is no appeal from the death sentence meted out for infractions of the convict code. Imagine being hunted through the jungles of Nam day after day for twenty years, and that will tell you a little of what prison is about. (16) 
Incarceration validates what Buell terms a "subjective place-attachment" (72). Buell also claims that place consciousness should be analysed as multi-dimensional, and that we should follow the ecocritic's insightful "mental mapping" of space where there are perplexing, abstract narratives underlying all locales (72). One dimension of space is rooted in a specific geographical location and points to the rise of a "concentric circle" of emotional identification (72). On the antipodes, place-attachment can be relevant to an "archipelago" of locations where "multiplication and dispersal" of emotions form place-consciousness (72). Baca appears to explore numerous versions of place attachment. He is in a limbo or a liminal phase between exclusion and inclusion, civil lack of freedom and sheer poetic liberty. Thus, on the one hand the prison is foregrounded as a place where he can successfully reinvent his self-identity and cultivate his poetic vocation. At the same time, however, the prison stands for the institutional power that deprives him of fundamental attributes of civilized being and contains him in a prison cell "steeped in self-loathing and rejected by everyone and everything-society, family, cons, God and demons" (11).

Despite being barred from his right to liberty and communal life, Baca resumes the power to resurrect as a poet or "as the burning ember floating in darkness on a dry leaf and sets flame to forests" (10-11). Images of devastation and regeneration alternate, revealing a schizoid or scalar attitude to experience. Baca speculates on his Chicano identity, American citizenship and subsequent imprisonment with ambivalent or contradictory emotions and the use of environmental imagery heightens this irresolute mood. Thus, he translates his poetic selfhood as "a burning ember" with references to the sweeping force of a blazing fire in a forest (10). Simultaneously, however, he replenishes imagery of environmental destruction with the use of the symbolic undertones in the growth of grass. The regenerative and liminal impact that poetry has on Baca allows him to re-enter the world as the humble grass, which multiplies and spreads among despotic trees. With the enticing metaphor of the grass, Baca's ecodiscourse construes poetic language as the vessel of his metamorphosis: "Through language I became the grass, speaking its language and feeling its green feelings and black root sensations. Earth was my mother and I bathed in sunshine. Minuscule speckles of sunlight passed through my green skin and metabolized in my blood" (11). In the unnatural confinement of a federal prison, "gazing at weeds and creosoted grass at the base of a telephone pole outside [his] grilled cell window," Baca has the epiphany of his poetic identity and lyrical logos, which resembles "water that cleansed the wound and fed the parched root of [his] heart" (11).

Contradictions and polarities lie at the heart of Baca's memoir. Firstly, Working in the Dark frequently deems the composition of poetry as a solitary endeavour of a poet's reflection and meditation despite the fact that the source of his inspiration originates in communal existence.

The poet's work is private and lonely. He must go to the woods and fast, must edge along the precipice of society and growl at the darkness, must be fearless in facing his own demons. He must put before all else the whispering whoo-whoo of the ocean in his blood, and treat his heart like a cowrie shell, constantly listening to the sounds of his heart and the murmuring sounds of the waves inside his heart 
that lure him to find their source in strange people, in strange places. [...] Only then may he be given the verse line or flash of understanding he has searched for, that weighs no more than the sigh of a flea. (42)

Secondly, Baca's understanding of the subtleties in the poetic craft conveys images of immense power as in the oceanic wave flow or in the demonic vigour of beastly creatures lurking in the darkness. On the other hand, the verse line is paralleled by a faint and feeble existence "like the sigh of a flea" (42). Thirdly, Baca reshuffles the romantic ideal of a sophisticated poet in a dystopian ivory tower set in untouched nature. Instead, he depicts the poet in physical captivity and completely dissociated from nature, while at the same time he resumes the mental power to escape incarceration and roam a natural setting at will.

At night I flew. [...] Before long I was frayed like a rope carrying too much weight, that suddenly snaps. I quit talking. Bars, walls, steel bunk and floor bristled with millions of poem-making sparks. [...] The only reality was the swirling cornucopia of images in my mind, the voices in the air. Mid-air a cactus blossom would appear, a snake-flame in blinding dance around it, stunning me like a guard's fist striking my neck from behind. (9)

For Baca, the material space for the composition of poetry is not subsumed in deified surroundings. Baca displaces or dethrones the poet from a remote, idolized locale of natural purity. In sharp contrast to the untainted physical space of the romantic tradition, Baca counter-proposes the bleakness of a prison cell as a site of inclusion in the realms of poetic diction. Baca reexamines standardized places for the conception and writing of belle lettres. For Baca, poetry should not be disconnected from the practicalities of everyday life or essentialized in a pseudo-worldly vista. Instead, he invigorates the composition of poetry in the solitude of a prison, which is a polysemous place per se: a site of exclusion from accepted behavioral norms and a site of inclusion in the undertaking of subversive contemplation. Staying persistently faithful to a destabilizing mode of thinking, Baca reveals the pinto poet as an outsider who has the pivotal opportunity to expound the essence of selfhood from an aberrant space.

\section{CONCLUSION}

In conclusion, Working in the Dark affixes depictions of nature as carriers of emotional purport throughout Jimmy Santiago Baca's vistas of spatial enactment. The natural world is also utilized as a powerful index of socio-political dictates. Baca's primary aim is not to indulge in the glorification of nature or to outline the environmental problems that the world is currently faced with. His extensive use of natural imagery is a figurative commentary on social dismay, cultural fossilization and personal trepidation. Baca's ethnopoetics is empowering on two accounts: it foregrounds the significance of the spatial parameter in identity-formation and also accords peripheral identities with a vibrant voice. Images of nature and visions of 
llano men and women "breathing hard [...] from the weight of the yoke of captivity," as well as noble ancianos, barrio inhabitants and urban hustlers populate the text as complementary to Baca's personal rise to the distinguished position of an acknowledged poet (27). In addition, although the narrative reflects the divergent mental routes of an ex-convict in search of self-awareness, the quaint space of a prison arises as the site which validates the emergence of Baca's liminalities, his Chicano cultural identity to effloresce and his personal sustenance to endure in the face of injustice.

Reviews sent to author: 10 May 2018

Revised paper accepted for publication: 9 July 2018 


\section{WORKS CITED}

BaCa, Jimmy Santiago: Working in the Dark: Reflections of a Barrio Poet. Santa Fe: Red Crane Books, 1992.

Внавна, Homi: “The Third Space: Interview with Homi Bhabha”, in Jonathan Rutherford (ed.), Identity: Community, Culture, Difference, London: Lawrence, 1990.

Buell, Lawrence: The Future of Environmental Criticism: Environmental Crisis and Literary Imagination. Malden: Blackwell Manifestos, 2005.

Clark, Timothy: The Cambridge Introduction to Literature and the Environment. Cambridge: Cambridge UP, 2011.

Foucault, Michel: "Different Spaces." Aesthetics, Method and Epistemology. Trans. Robert Hurley. Ed. James D. Faubion. New York: The New P, 1998. 175-86.

Garrard, Greg: Ecocriticism. London, New York: Routledge, 2012.

Gates, Henry Louis Jr.: The Signifying Monkey: A Theory of African American Literary Criticism. New York: Oxford UP, 1988.

Gramsci, Antonio: "Notes for an Introduction and an Approach to the Study of Philosophy and the History of Culture." David Forgacs (ed.). The Antonio Gramsci Reader: Selected Writings 1916-1935. New York: New York UP, 2000. 323-347.

Lefebvre, Henry: The Production of Space. Trans. Donald Nicholson-Smith. Oxford: Blackwell, 1991.

León Portilla, Miguel (ed.): The Aztec Image of Self and Society: An Introduction to Nahua Culture. Salt Lake City: U of Utah P, c1992.

Lomelí, Francisco A. and Donaldo W. Urioste (ed.): Chicano Literature and Criticism. Albuquerque, N.M.: Pajarito Publications, c1977.

Malpas, J.E.: Place and Experience: A Philosophical Topography. Cambridge: Cambridge UP, 1999.

Martínez, Julio A. and Francisco A. Lomelí (ed.): Chicano Literature: A Reference Guide. Westport, Conn.: Greenwood Press, 1985.

Murphy, Patrick D.: Farther Afield in the Study of Nature-Oriented Literature. Charlottesville and London: U of Virginia P, 2000.

Pérez-Torres, Rafael: Movements in Chicano Poetry: Against Myths, Against Margins. Cambridge: Cambridge UP, 1995.

Sessions, G. (ed.): Deep Ecology for the Twenty-first Century: Readings on the Philosophy and practice of the New Environmentalism. London: Shambhala, 1995.

Saldívar, Ramón: Chicano Narrative: The Dialectics of Difference. Madison Wis.: U of Wisconsin P, 1990.

Soja, W. Edward: Postmodern Geographies: The Reassertion of Space in Critical Social Theory. London: Verso, 1989.

Turner, Victor: From Ritual to Theatre: The Human Seriousness of Play, New York: Performing Arts Journal Publishers, 1982.

Tuan, Yi-Fu: Space and Place: The Perspective of Experience. Minneapolis: U of Minnesota P, 1977. 